\title{
ANALISIS HUKUM TERHADAP KEUANGAN BADAN USAHA MILIK NEGARA SEBAGAI KEUANGAN NEGARA
}

\author{
Radisman Saragih \\ radisman.saragih@uki.ac.id \\ Universitas Kristen Indonesia, Jakarta, Indonesia
}

\begin{abstract}
Regulations governing the country's nances embrace the state's nancial concept in a broad sense, the state's nances not only cover the nances in the BUDGET only, but also includes the BUDGET-separated to the government District (APBD), to the state-owned enterprises, to the BUMD and to other agencies and all State property assets that can be assessed by money. Thus, the nancial in the BUDGET and nancial that has been separated into nance APBD. Become a nancial BUMN, become nance BUMD, and become another nancial entity, as well as all state nances are a state nancial system. Act No. 17 year 2003 on state nances, Law No. 19 of 2003 on state-owned enterprises, Law No. 1 of 2004 concerning the national law on $\neg$ haration, Act No. 15 year 2004 on management inspections and other state nancial liabilities and statutory regulations, including the CONSTITUTION 1945 post-amendment which is the statutory regulation in the State nancial eld is including public law areas.
\end{abstract}

Keywords: APBD; nance; constitution.

\section{Pendahuluan}

Secara konsepsional dan konstitusional, masalah keuangan negara telah diatur dalam UUD 1945, baik UUD 1945 (naskah asli, pra amandemen), maupun dalam UUD 1945 (pasca amandemen, sesudah perubahan). Dalam UUD 1945 pra amandemen, masalah keuangan negara diatur dalam pasal 23 ayat 1 , 2, 3, 4 dan 5. Sedangkan dalam UUD 1945 pasca amandemen, masalah keuangan negara tetap diatur dalam pasal 23, namun pasal 23 ini sudah diperluas atau ditambah dan dirinci ke dalam pasal 23 ayat 1,2 dan 3; pasal 23 A pasal $23 \mathrm{~B}$, pasal $23 \mathrm{C}$ dan pasal 23 D. Sementara itu, dalam pasal $23 \mathrm{E}$ ayat 1, 2 dan 3; pasal $23 \mathrm{~F}$ ayat 1 dan 2; pasal $23 \mathrm{G}$ ayat I dan 2, diatur tentang Badan Pemeriksa Keuangan (BPK) yang nota bene diadakan/dibentuk untuk memeriksa pengelolaan dan tanggungjawab tentang keuangan negara.

Walaupun dalam pasal 23 UUD 1945, baik pra amandemen maupun pasca amandemen, sudah diatur masalah keuangan negara, namun ketentuan pasal 23 tersebut tidak memuat dan tidak memberikan pengertian keuangan negara, sehingga pemahaman mengenai arti keuangan negara belum mempunyai pemahaman yang sama, baik dikalangan para ahli maupun di dalam peraturan perundang-undangan. Pengertian keuangan negara yang dibuat oleh para ahli dan pengertian keuangan negara sebagaimana dirumuskan dalam peraturan perundang-undangan ada kemungkinannya mempunyai persamaan, dan juga kemungkinan mempunyai perbedaan.

Beberapa pendapat para ahli tentang keuangan negara dapat dikemukakan sebagai berikut: 1

1. Menurut Geodhart, keuangan negara merupakan keseluruhan undang-undang yang ditetapkan secara periodik yang memberikan kekuasaan pemerintah untuk melaksanakanpengeluaran mengenai periode tertentu dan menunjukkan alat pembiayaan yang diperlukan untuk menutup pengeluaran tersebut.

Dalam pengertian ini, terdapat unsur-unsur keuangan negara, yakni a), periodik; b), pemerintah sebagai pelaksana anggaran; c), pelaksanaan anggaran mencakup dua wewenang, yaitu wewenang pengeluaran dan wewenang untuk menggali sumbersumber pembiayaan

1 W. Riawan Tjandra, Hukum Keuangan Negara. (Jakarta: Grafindo, 2006), hal. 1-2. 
untuk menutup pengeluaran-pengeluaran yang bersangkutan, dan d), bentuk anggaran negara adalah berupa suatu Undang-Undang.

2. Menurut van der Kemp. keuangan negara adalah semua hak yang dapat dinilai dengan uang, demikian pula segala sesuatu, baik berupa uang maupun barang yang dapat dijadikan milik negara berhubungan dengan hak-hak tersebut.

3. Menurut John F. Due, Budget (anggaran belanja) adalah suatu rencana keuangan untuk suatu periode waktu tertentu. Government budget (anggaran belanja pemerintah) adalah suatu pernyataan mengenai pengeluaran atau belanja yang diusulkan dan penerimaan yang untuk masa mendatang bersama dengan data pengeluaran dan penerimaan yang sebenarnya untuk periode mendatang dan periode yang telah lampau. Dalam pengertian anggaran belanja pemerintah, terdapat unsur-unsurnya yakni: a), anggaran belanja yang memuat data keuangan mengenai pengeluaran dan penerimaan dan tahun-tahun yang sudah lalu; b), jumlah anggaran yang diusulkan untuk tahun yang akan dating; c), jumlah taksiran untuk tahun yang sedang berjalan; d), rencana keuangan tersebut untuk suatu periode tertentu.

Dan pengertian keuangan negara menurut John F. Due timbul kesan bahwa John F. Due mengidentikkan pengertian keuangan negara dengan anggaran belanja pemerintah. Ditinjau dari kedudukan anggaran negara dalam penyelenggaraan negara, hal itu dapat dipahami, tetapi apabila dikaitkan dengan Anggaran Pendapatan dan Belanja Negara (APBN), hal tersebut kurang tepat. Dalam konteks ini, Muchsan berpendapat bahwa ada hubungan yang erat antara anggaran negara dengan keuangan negara, yaitu anggaran negara merupakan inti dari keuangan negara, sebab anggaran negara merupakan alat penggerak untuk melaksanakan keuangan negara.

4.Menurut Rekomendasi Seminar 1CW (Indische Comptabiliteitwet) tanggal 30 Agustus - 5 September 1970 di Jakarta, keuangan negara adalah semua hak dan kewajiban yang dapat dinilai dengan uang dari segala sesuatu, baik berupa uang maupun berupa barang yang dapat dijadikanmilik negara berhubungan dengan pelaksanaan hak dan kewajiban tersebut.

Sementara itu, perundang-undangan dalam bidang anggaran negara atau keuangan negara merumuskan pengertian keuangan negara sebagai berikut: Menurut pasal 3 Undang-Undang No. 17 Tahun 1965 Tentang Penetapan Peraturan Pemerintah Pengganti UndangUndang No. 6 Tahun 1964 Tentang Pembentukan Badan Pemeriksa Keuangan (UU. No 17 Tahun 1965 sudah dicabut dengan Undang-Undang No. 5 Tahun 1973 Tentang Badan Pemeriksa Keuangan), yang dimaksud dengan keuangan negara dalam Undangundang ini adalah segala kekayaan negara dalam bentuk apapun juga, baik terpisah maupun tidak.

Sedangkan dalam penjelasan UU No. 17 Tahun 1965 (Tambahan Lembaran Negara, TLN Nomor 2776 merumuskan pengertian keuangan negara sebagai berikut : "Dengan keuangan negara tidak hanya dimaksud uang negara, tetapi seluruh kekayaan negara, termasuk didalamnya, segala hak serta kewajiban yang timbul karenanya, baik kekayaan itu berada dalam penguasaan dan pengurusan pada pejabat-pejabat dan/ atau lembaga- lembaga yang termasuk pemerintahan umum., maupun berada dalam penguasaan dan pengurusan bank-bank pemerintah, Yayasan-Yayasan pemerintah, dengan status hukum publik ataupun privat, perusahaan-perusahaan negara dan usaha-usaha dimana pemerintah mempunyai kepentingan khusus, serta penguasaan dan pengurusan fihak lain maupun berdasarkan perjanjian dengan penyertaan (partisipasi) pemerintah ataupun penunjukkan dari pemerintah".

Demikian juga dalam pasal 1 angka 1 UndangUndang Nomor 17 Tahun 2003 Tentang Keuangan Negara merumuskan pengertian keuangan negara sebagai berikut: "Keuangan Negara adalah semua hak dan kewajiban negara yang dapat dinilai dengan uang, serta segala sesuatu baik berupa uang maupun berupa barang yang dapat dijadikan milik negara berhubung dengan pelaksanaan hak dan kewajiban tersebut". Menurut M. Subagio, hak negara itu meliputi hak menciptakan uang, hak mendatangkan hasil, hak melakukan pungutan, hak meminjam dan hak memaksa, sedangkan kewajiban negara meliputikewajiban menyelenggarakan tugas negara 
demi kepentingan masyarakat, dan kewajiban membayar hak-hak tagihan pihak ketiga.2

Disamping pengertian keuangan negara menurut para ahli dan peraturan perundang-undangan tersebut di atas, tetapi juga ada pendapat yang mengemukakan keuangan negara itu dalam arti sempit dan dalam arti luas. Keuangan negara dalam arti sempit adalah keuangan negara yang berasal dari bersumber pada APBN saja, sebagai sub sistim dan sistim keuangan negara. Singkat kata, keuangan negara adalah sama artinya dengan APBN. Sedangkan keuangan negara dalam arti luas adalah keuangan negara yang berasal / bersumber dari APBN, APBD, BUMN dan pada hakekatnya seluruh harta kekayaan negara sebagai sesuatu sistem keuangan negara.

Dari pemahaman negara dalam arti luas tersebut dapat diketahui bahwa keuangan negara itu sangat harus mencakup keuangan yang berada dalam APBN, keuangan yang berada dalam APBD, keuangan yang berada dalam BUMN, keuangan yang berada dalam BUMD dan seluruh kalangan negara dalam bentuk apapun, baik keuangan yang dipisahkan ataupun tidak dipisahkan, termasuk didalamnya segala bagian kekayaan negara dan segala hak di kewajiban yang timbul karenanya. Dengan perkataan lain, keuangan APBN adalah merupakan bagian dari keuangan negara, keuangan APBD adalah merupakan bagian dari keuangan negara, keuangan BUMN adalah sebagai bagian dari keuangan negara, dan keuangan BUMD adalah sebagai bagian dari keuangan negara.

Dalam penulisan ini hanya mengkaji dan membahas keuangan BUMN sebagai bagian dari keuangan negara saja. Pembahasan terhadap keuangan BUMN sebagai bagian keuangan negara dengan pendekatan atau perspektif Juridis (hukum). Perspektif Juridis (hukum) dalam hal ini tentu yang ada hubungannya dengan keuangan negara, baik bidang hukum publik maupun hukum privat Bidang Hukum Publik dan hukum privat yang mempunyai hubungan signifikan dengan masalah keuangan negara dan keuangan BUMN adalah Hukum Konstitusi atau Hukum Tata Negara, Hukum

2 M. Subagio, Hukum Keuangan Negara RI, (Jakarta: Rajawali Press, 1988), hal. 11-12.
Administrasi Negara (Hukum Tata Usaha negara), lebih khusus dan terutama Hukum Anggaran Negara atau Hukum Perbendaharaan Negara. 3

Berdasarkan apa yang diuraikan di atas sebagaimana dapat diketahui bahwa masalah keuangan BUMN sebagai keuangan negara tidak hanya dapat dibahas dan dianalisis dari perspektif hukum saja, tetapi juga dapat dibahas terutama dari perspektif ilmu ekonomi ataupun ilmu sosial lainnya seperti ilmu administrasi, ilmu politik dan ilmu pemerintahan. Pemahaman mengenai arti keuangan negara, demikian juga keuangan BUMN sebagaimana dipaparkan di atas, hanyalah dari tinjauan juridis atau perspekitif hukum semata-mata, belum dari tinjauan ilmu ekonomi misalnya. Dengan demikian dapat dipahami bahwa masalah keuangan negara maupun aspek dan ruang lingkup yang cukup luas, karena ditinjau dari aspek ilmu hukum, ilmu ekonomi atau aspek ilmu sosial lainnya. Berikut ini disusun dan dibuat definisi operasional dari konsep-konsep terkait, guna mempertegas pengertian dan menghindar dari kesalah pahaman, sekaligus untuk memberikan acuan dalam proses penulisan makalah ini.

Adapun definisi opcratsional yang dimaksud dalam penulisan ini adalah sebagai berikut:

1. Keuangan negara adalah semua hak dan

kewajiban negara yang dapat dinilai dengan

uang, serta segala sesuatu hak berupa uang

maupun berupa barang yang dapat dijadikan

milik negara berhubungan dengan pelaksanaan

hak dan kewajiban tersebut.4

Pengertian keuangan negara sebagaimana diatur dan dimuat dalam pasal 1 angka 1 Undang-Undang Nomor 17 Tahun 2003 ini identik atau dipersamakan dengan "keuangan negara dalam arti luas", yaitu keuangan yang berada dalam APBN, dalam APBD, dalam BUMN dalam BUMD dan seluruh kekayaan negara dalam bentuk apapun, baik kekayaan negara yang dipisahkan ataupun

3 Istilah Hukum Perbendaharaan Negara melupakan singkatan dari istilah "Hukum Administrasi Perbendaharaan atau "Comptabel Administraliefrechr. Menurut Arifin P. Soenia Atmadja, Hukum Administrasi Perbendaharaan Negara disebut juga Hukum Perbendaharaan Negara oleh Fakultas Pascasarjana Universitas Padjadjaran, dan FR Universitas Indonesia menyebutnya "Hukum Anggaran Negara, Lihat : Arifin P. Soeria Atinadja, Mekanisme Pertanggungjawaban Keuangan Negara, Suatu Tinjauan Juridis (Jakarta: Gramedia, 1986), kata pengantar, hal. XIII.

4 Indonesia, Undang-Undang Tentang Keuangan, UIndang-Undang RI. Nomor 17 Tahun 2003, pasal 1 angka 1. 
tidak dipisahkan.5

2. Badan Usaha Milik Negara, yang selanjutnya disebut BUMN, adalah badan usaha yang seluruh atau sebagian besar modalnya dimiliki oleh negara melalui penyertaan secara langsung yang berasal dari kekayaan negara yang dipisahkan.6

3. Keuangan Badan Usaha Milik Negara, yang selanjutnya disebut Keuangan BUMN, adalah keuangan yang be dan keuangan negara dan/atau kekayaan negara yang dipisahkan dan ditempatkan atau berada dalam Badan Usaha Milik Negara. 7

4. Subjek hukum adalah setiap orang yang diakui sebagai pemegang atau pengemban hak dan kewajiban dalam hubungan hukum atau perbuatan hukum, yaitu manusia (subjek hukum orang) dan badan hukum (subjek hukum bukan orang). 8

5. Badan hukum adalah suatu badan yang ada karena hukum dan memang diperlukan keberadaannya sehingga disebut “Legal entity” Menurut Henry Campbell Black (Black's Law Dictionary), legal entity adalah "legal existence. an entity other than natural person, who has sufficient existence in legal contemplation that it corn function legally, he sued or sue and make decisions through agents as in the case of corporations". 9 Badan hukum adalah subjek hukum yang berarti badan hukum diakui sebagai pemilik, pengemban, pendukung hak dan kewajiban dalam hubungan-hubunganhukum, sebagaimana layaknya orang (manusia) yang juga merupakan subjek hukum.

6. Perbendaharaan negara adalah pengelolaan dan pertanggungjawaban keuangan negara, termasuk investasi dan kekayaan yang dipisahkan, yang ditetapkan dalam APBN dan APBD.10

7. Barang milik negara ialah semua barang yang

5 Diadop dan disarikan dari pendapat para ahli dengan rumusan pengertian keuangan Negara sebagaimana dimuat/diatur dalam Penjelasan Undang-Undang Nomor 17 Tahun 1965, Tambahan Lembaran Negara Nomor 2776.

6 Indonesia, Undang-Undang Tentang Badan Usaha Milik Negara, Undang-Undang RI Nomor 19 Tahun 2003, pasal 1 angka.

7 Pengambil-alihan dan perpaduan antara pengertian keuangan negara sebagaimana dimaksud dalam pasal 1 angka 1 UU. No. 17 Tahun 2003 dengan pengertian BUMN sebagaimana dimaksud dalam pasal I angka 1 UUNo. 19 Tahun 2003.

8 LG. Rai Widjaya, Hukum Perusahaan, (Jakarta : Megapoin, 2002), hal 127

9 Ibid., hal. 128

10 Indonesia, Undang-Undang Tentang Perbendaharaan Negara, Undang-Undang Nomor 1 Tahun 2004, pasal 1 angka 1. dibeli atau diperoleh atas beban APBN atau

berasal dari perolehan lainnya yang sah.11

8. Kekayaan negara yang dipisahkan adalah kekayaan negara yang berasal dari Anggaran Pendapatan dan Belanja Negara (APBN) untuk dijadikan penyertaan modal negara pada persero dan/atau Perum serta Perseroan Terbatas lainnya.

9. Perusahaan Negara adalah badan usaha yang seluruh atau sebagian modalnya dimiliki oleh Pemerintah Pusat.12

10. Anggaran Pendapatan dan Belanja Negara., selanjutnya disebut APBN, adalah rencana keuangan tahunan pemerintahan negara yang disetujui oleh Dewan Perwakilan Rakyat.13

\section{Pembahasan}

1. Konsepsi Keuangan Negara Dalam Perspektif Hukum

Masalah keuangan negara sebagai hal yang pokok dan memegang peranan penting dalam suatu negara, sehingga dapat dikatakan keuangan negara merupakan motor penggerak bagi negara dalam melaksanakan/ menjalankan roda pemerintahan. Demikian vital dan pentingnya masalah keuangan negara, sehingga masalah keuangan negara selalu diatur dalam kostitusi negara, termasuk negara Indonesia, sebagaimana diuraikan di atas, masalah keuangan negara sudah diatur dalam Pasal 23 UUD 1945, baik pra amandemen maupun pasca amandemen Kendati masalah keuangan negara sudah diatur dalam pasal 23 UUD 1945 tersebut, namun pasal 23 itu tidak memuat pengertian keuangan negara. Dalam konteks yang demikian, persepsi mengenai pengertian keuangan negara belum mempunyai pemahaman yang sama, terutama dikalangan para ahli. Oleh karena itu para ahli mencoba membuat penafsiran atau interpretasi terhadap ketentuan pasal 23 UUD 1945 tersebut.

Menurut Rochmat Soemitro, penafsiran terhadap pasal 23 UUD 1945 perlu dilakukan, karena ketentuan pasal 23 UUD 1945 tersebut "Tidak dapat menarik kesimpulan apa yang dimaksudkan dengan keuangan

$\overline{11 \text { Ibid, pasal } 1 \text { angka }} 10$

12 Indonesia, Undang-undang Tentang BUMN, Undang-Undang No. 19 Tahun 2003, pasal 1 angka 10.

13 Indonesia, Undang-Undang Tentang Keuangan Negara, Undang-Undang No. 17 Tahun 2003, pasal 1 angka 5. 
negara".14 Dengan tidak adanya pengertian keuangan negara dimuat atau diatur dalam UUD 1945 pra amandemen dan pasca amandemen, menurut pandangan Dian Puji N. Simatupang menunjukkan ketidak mampuan konstitusi Indonesia merumuskan pengertian keuangan negara. Menurut kebiasaan dalam ilmu pengetahuan hukum, apabila dalam suatu undang-undang tidak ditemukan pengertian mengenai sesuatu istilah hukum, maka para ahli umumnya membuat/ melakukan penafsiran atau interpretasi terhadap istilah hukum tersebut.

Dalam pengamatan Dian Puji N. Simatupang, paling tidak ada tiga interpretasi atau penafsiran terhadap pasal 23 UUD 1945 yang dibuat para ahli mengenai defmisi atau pengertian keuangan negara, yaitu: ${ }^{15}$ Penafsiran Pertama, "Pada pokoknya menyatakan pengertian keuangan negara diartikan secara sempit, dan untuk itu dapat disebutkan sebagai keuangan negara dalam arti sempit, yang hanya meliputi keuangan negara yang bersumber pada Anggaran Pendapatan dan Belanja Negara (APBN), sebagai sub sistem dan suatu sistem keuangan negara dalam arti sempit”. Mengenai penafsiran pertama ini, selanjutnya Dian Puji N. Simatupang mengatakan bahwa makna keuangan negara dalam rumusan penafsiran tersebut di atas adalah semua aspek yang tercakup dalam APBN yang diajukan oleh Pemerintah kepada DPR setiap tahunnya. Dengan kata lain, APBN merupakan diskripsi dari keuangan negara, sehingga pengawasan terhadap APBN juga merupakan pengawasan terhadap keuangan negara.

Sementara itu, penafsiran kedua adalah berkaitan dengan metode sistematik dan historis yang menyatakan: "Keuangan negara dalam arti luas, yang meliputi keuangan negara yang berasal dari APBN, APBD, BUMN, BUMD, dan pada hakekatnya seluruh kekayaan negara, sebagai suatu sistim keuangan negara...." Dalam penafsiran kedua menurut Puji N.

Simatupang, terkandung pengertian keuangan negara sebagai segala sesuatu kegiatan atau aktivitas yang berkaitan erat dengan uang yang dibutuhkan oleh negara untuk kepentingan publik. Dengan kata lain,

14 Rochmat Soernitro, "Tanggung Jawab Keuangan Nega-ra". Padjadjaran 2 (April - Juni 1981), hal 4.

15 Dian Puji N. Simatupang, Determinasi Kebaikan Anggaran Negara Indonesia, Studi Yuridis, (Jakarta: Papas Sinar Sinanti, 2005). hal. 48 - 49. esensi keuangan negara sama dengan kekayaan negara yang terdiri atas aktiva dun passiva. semua barang yang mempunyai nilai uang seperti tanah, tambang, gunung, yang ada di wilayah Republik Indonesia dan juga semua sarana yang dimiliki negara Republik Indonesia, baik yang berasal dari pembelian maupun dan cara perolehan lainnya.

Terakhir, penafsiran ketiga yang dilakukan melalui pendekatan sistematik dan teleologis atau sosiologis terhadap keuangan negara, dengan mengatakan sebagai berikut "Apabila tujuan menafsirkan keuangan negara tersebut dimaksudkan uniuk mengetahui sistim pengurusan dan pertanggungjawabannya, maka pengertian keuangan negara tersebut adalah sempit. Selanjutnya pengertian keuangan negara apabila pendekatannya dilakukan dengan menggunakan cara penafsiran sistematis dan teologis, maka pengertian keuangan negara itu adalah dalam pengertian keuangan negara dalam arti luas, yakni termasuk didalamnya keuangan yang berada dalam APBN, APBD, BUMN, BUMD dan pada hakikatnya seluruh kekayaan negara merupakan objek pemeriksaan dan pengawasan".

Penafsiran ketiga tersebut di atas, sejalan dengan pendapat A. Hamid S. Attamimi dalam memahami atau menggantikan keuangan negara. Dalam rangka menjelaskan pengertian keuangan negara, beliau mengupas (membahas) pasal 23 ayat 1 dan membandingkannya dengan pasal 23 ayat 5 UUD 1945 Pra amandemen, disatu segi, dan juga mengupas (membahas) pasal 23 ayat 1 dan membandingkannya dengan pasal 23 ayat 4, di lain segi Pembahasan terhadap pasal 23 ayat 1 membandingkannya terhadap pasal 23 ayat 5 disebutnya konstruksi pertama, sedangkan pembahasan pasal 23 ayat 1 dan membandingkannya terhadap pasal 23 ayat 4 disebutnya konstruksi kedua. Kedua konstruksi mi dibuatnya dalam kerangka menjawab pertanyaan Apakah yang dimaksud dalam ayat 5 mengenai diadakannya BPK untuk memeriksa tanggung jawab tentang “Keuangan negara?" Apakah kata-kata "Keuangan negara" dalam ayat 5 ini hanyalah APBN semata-mata ataukah APBN 'plus' lainnya?

Adapun konstruksi pertama dan konstruksi kedua mengenai pengertian keuangan negara dijelaskan oleh 
A. Hamid S. Attamimi sebagai berikut: ${ }^{16}$

- Konstruksi pertama, ayat 1 menentukan bahwa APBN harus ditetapkan dengan Undang-Undang. Ayat 5 menentukan bahwa BPK diadakan untuk memeriksa tanggung jawab tentang keuangan negara. Penjelasan ayat 5 menyebutkan, bahwa untuk memeriksa tanggung jawab pemerintah tentang tata cara mempergunakan uang belanja yang sudah disetujui DPR itu, perlu adanya BPK. Jadi meskipun dalam avat 5 sendiri tidak disebut APBN melainkan hanya keuangan negara, namun penjelasan ayat 5 tersebut menunjuk kepada APBN. Dengan demikian, maka yang dimaksud dengan "keuangan negara adalah APBN". Singkat kata, keuangan negara dalam pengertian konstruksi pertama ini adalah identik atau sama dengan APBN.

- Konstruksi Kedua, ayat 1 menentukan bahwa APBN harus ditetapkan dengan Undang-Undang. Ayat 4 menentukan bahwa hal keuangan negara harus diatur dengan Undang-Undang. Dan kedua ayat ini jelas terlihat bahwa pengertian APBN dan keuangan negara perlu diteliti lebih lanjut apakah sama ataukah dua hal yang berbeda, sebab apabila merupakan hal yang sama tentunya tidak perlu diatur dalam ayat 1 dan ayat 4 secara terpisah, cukup dalam satu ayat saja. Ditambah lagi, pada ayat 1 ditetapkan dengan Undang-Undang, sedangkan pada ayat 4 diatur dengan UndangUndang. Jadi, pada ayat (1) Undang-Undang APBN tersebut bersifat formal, sedangkan pada ayat 4 Undang-Undang Keuangan Negara tersebut bersifat materiil dan juga formal. Apakah dengan demikian BPK hanya memeriksa keuangan negara saja seperti tercantum dalam ayat 5 dan tidak memeriksa APBN, karena keuangan negara dan APBN seolah-olah dua hal yang berbeda? Disinilah fungsi penjelasan ayat 5 . Penjelasan ayat 5 menyebutkan bidang konkrit tentang tanggung jawab pemerintah dalam keuangan negara (cara mempergunakan uang belanja negara yang sudah disetujui DPR agar sepadan dengan UU APBN),

16 A. Hamid S. Attamimi, Pengertian Keuangan Negara menurut UUD 1945 pasal 23, dalam Padma Wahjono (Penghimpun), Masalah Ketatanegaraan Indonesia Dewasa ini, Jakarta: Ghalia Indonesia. 1984). hal. 281-282. karena ayat 5 yang menyebut "keuangan negara" itu oleh penjelasannya disebut bidang konkrit penggunaan APBN.

Berdasarkan konstruksi kedua dari penafsiran ketiga sebagaimana diuraikan di atas dapat dikatakan bahwa ketentuan pasal 23 ayat 1 dan ayat 5 UUD 1945 pra amandemen menegaskan definisi/ pengertian keuangan negara yang menjadi objek pemeriksaan BPK adalah APBN dan keuangan negara diluar APBN. Hal ini sesuai dengan pendapat A. Hamid S. Attamimi, bahwa keuangan negara yang pemeriksaan terhadap tanggung jawab penyelenggaraannya merupakan tugas BPK dan hasil pemeriksaannya diberitahukan kepada DPR itu bukan hanya APBN yang ditetapkan tiap tahun dengan Undang-undang, melainkan meliputi juga APBN yang dipisahkan, baik dipisahkan kepada pemerintah daerah, kepada Badan Usaha Milik Negara, Badan Usaha Milik Daerah, maupun kepada badan lainnya." 17

Berbeda dengan pendapat A. Hamid S. Attamimi tersebut, ternyata BPK sebagai lembaga pengawasan eksternal keuangan negara, justru menganut penafsiran yang lebih luas lagi. BPK berpendapat bahwa maksud keuangan negara adalah penerimaan dan pengeluaran negara keseluruhan, kekayaan harta negara seluruhnya, kebijakan sektor anggaran, fiskal, moneter, dan akibatnya, serta keuangan lainnya. Pendapat BPK yang demikian, menurut Dian Puji N. Simatupang, mengandung makna bahwa BPK mempunyai keleluasaan dan tanggung jawab dalam memeriksa keuangan negara seluruhnya, tanpa kecuali.18

Pendapat luas mengenai pengertian keuangan negara dan BPK tersebut merupakan upaya BPK untuk memperluas definisi keuangan negara, sehingga objek pemeriksaannya juga meluas. Upaya ini ternyata dikukuhkan dan dilegitimasi dalam UUD 1945 pasca amandemen dengan mencantumkan/ mengaturnya dalam pasal $23 \mathrm{G}$ yang memberikan kewenangan BPK membuka kantor perwakilan di setiap provinsi. Di samping itu juga tugas BPK semakin luas, dari semula menurut UUD 1945 pra amandemen hanya bertugas memeriksa tanggung jawab keuangan negara (lihat pasal 23 ayat 5 UUD 1945 pra amandemen, naskah asli), menjadi bertambah, yaitu di samping untuk

17 Dian Puji N. Simatupang, op. cit, hal. 50.

18 Ibid, hal. 51. 
memeriksa tanggung jawab, tetapi juga memeriksa pengelolaan keuangan negara (lihat pasal $23 \mathrm{E}$ ayat I UUD 1945 pasca amandemen). Dengan pengertian luas tentang keuangan negara dan adanya tugas BPK selain memeriksa pertanggung jawaban tetapi juga pengelolaan keuangan negara, menurut Dian Puji

N Simatupang akan menurunkan derajat BPK yang menginginkan lembaga audit yang bersifat pre-audit selayaknya audit internal pemerintah. ${ }^{19}$

Penulis sendiri setuju dengan pendapat Dian Puji

N Simatupang dalam hal adanya kewenangan BPK membuka kantor perwakilan disetiap provinsi (pasal $23 \mathrm{G}$ ayat 1 UUD 1945 pasca amandemen), dan dalam hal turunnya derajat BPK sebagai lembaga tinggi negara dan sebagai lembaga eksternal keuangan negara berdasarkan alasan-alasan:

a. Membebankan BPK sebagai lembaga tinggi negara untuk memeriksa seluruh pengelolaan keuangan negara, tanpa kecuali. Dengan tugas pemeriksaan yang terlalu luas, menimbulkan rentang kendali yang terlalu sulit dijangkau, sehingga pemeriksaan atau pertanggung jawaban terhadap keuangan negara kemungkinannya menjadi tidak maksimal dan optimal;20

b. Adanya keinginan BPK sebagai lembaga pengawasan yang bersifat pre - audit seperti layaknya audit internal Pemerintah, menimbulkan kesan bahwa BPK sebagai bagian dari pemerintah, padahal menurut pasal $23 \mathrm{E}$ ayat 1 seharusnya merupakan lembaga yang bebas dan mandiri, dengan maksud dan tujuansupayafungsi mengawasannya terhadap keuangan negara yang dikelola oleh pemerintah berjalan efektif dan maksimal, karena selain fungsi pengawasan (fungsi operatif), tetapi juga BPK masih mempunyai fungsi pertimbangan (rekomendasi) dan fungsi peradilan.21

c. Dengan melakukan pengawasan yang bersifat pre audit, maka tugas BPK ada kemungkinannya menjadi berbenturan dan mengurangitugas-tugas

19 Ibid.,

20 Dian Puji N Simatupang, "Hukum Anggaran dan Keuangan Negara dalam : Safri Nugraha, dkk.

21 BPK. dalam menjalankan tugasnya mempunyai 3 (tiga) fungsi, yaitu fungsi operatif (pengawasan), fungsi pertimbangan (rekomendasi), dan fungsi peradilan, bandingkan: Yuswar Zainul Basri dan Mulyadi Subri "Keuangan Negara dan Analisis Kebijakan Utang Luar Negeri”, (Jakarta: Raja Grafindo Persada, 20003), hal 7. pengawasan yang ada dalam badan pemerintahan, misalnya dengan tugas Badan Pengawasan Keuangan dan Pembangunan (BPKP), dengan Kantor Perbendaharaan Negara, dengan Inspektorat Jenderal pada Kementerian atau Departemen atau badan /lembaga non Departemen, dengan Irjenbang atau Inspektorat Jenderal untuk proyek-proyek pembangunan yang berada langsung dibawah Presiden ataupun dengan badan lembaga pemerintah lainnya." 22

\section{Konsepsi Keuangan Badan Usaha Milik Negara} dalam Perspektif Hukum

Sebelum menganalisis keuangan Badan Usaha Milik Negara, selanjutnya disebut BUMN, ada baiknya terlebih dahulu diketahui pengertian BUMN tersebut. Pasal 1 angka 1 Undang-Undang Nomor 19 Tahun 2003 menentukan bahwa "Badan Usaha Milik Negara adalah badan usaha yang seluruh atau sebagian besar modalnya dimiliki oleh negara melalui penyertaan secara langsung yang berasal dari kekayaan negara yang dipisahkan". Dengan berpatokan pada pengertian BUMN ini, dan menambahkan serta merangkai dengan kata keuangan di depan kata BUMN maka terjadilah kata-kata "keuangan BUMN Selanjutnya dengan mengambil alih pengertian BUMN maka dapat juga dirumuskan pengertian keuangan BUMN sebagai

"keuangan dalam atau berada dalam badan usaha yang seluruh atau sebagian besar modalnya dimiliki oleh negara melalui penyertaan secara langsung yang berasal dan kekayaan negara yang dipisahkan " 23

Rumusan pengertian BUMN dalam pasal 1 angka

1 Undang-Undang Nomor 19 Tahun 2003 tersebut sangat erat kaitannya dengan keuangan negara, terutama mengenai apa yang dimaksud dengan "kekayaan negara yang dipisahkan". Menurut pasal

1 angka 10 Undang-Undang Nomor 19 Tahun 2003,

22 Aparat pengawasan BPK disebut Pengawas Ekstern sedangkan aparat pengawasan dalam pemerintahan disebut Pengawas Intern. Aparat pengawas intern dalam Lingkungan Pemerintah adalah BPKP. Kantor Perbendaharaan Negara, Irjenbang dan Inspektorat Jenderal Kementerian/ Departemen dan Lembaga non Departemen (Bandingkan: Edi Soepangat dan Haposan Lumban Gaol), Pengantar Ilmu Keuangan Negara (Jakarta: STIE Perbanas dan Gramedia, 1991), hal. 200 -201.

23 Penulis membuat pengertian keuangan BUMN tersebut diatas dengan maksud untuk mempermudah memahaminya dan menghubungkannya dengan keuangan negara. 
bahwa yang dimaksud dengan "Kekayaan negara yang dipisahkan adalah kekayaan negara yang berasal dari Anggaran Pendapatan dan Belanja Negara (APBN) untuk dijadikan penyertaan modal negara pada Persero dan/atau Perusahaan Umum Perum) serta perseroan terbatas lainnya". Dengan demikian, keuangan BUMN bersumber atau berasal dari Anggaran Pendapatan dan Belanja Negara yang nota bene merupakan bagian dari keuangan negara dalam arti luas sebagaimana telah diuraikan di atas.

Keuangan BUMN sebagai keuangan yang bersumber atau berasal dari Anggaran Pendapatan dan Belanja Negara akan dijadikan sebagai penyertaan modal negara pada Persero dan/atau Perusahaan Umum dan perseroan terbatas lainnya. Dengan kata lain, modal yang terdapat atau berada pada Persero dan/ atau Perusahaan Umum dan perseroan terbatas lainnya itu merupakan modal negara sekaligus merupakan kekayaan negara yang dipisahkan dan bersumber atau berasal dari APBN, yang nota bene adalah bagian dan keuangan negara dalam arti luas.

Dari ketentuan pasal 1 ayat 1 Undang-Undang No. 19 Tahun 2003 tersebut dapat juga diketahui bahwa badan usaha milik negara itu adalah badan usaha yang berbentuk Persero dan/atau Perusahaan Umum dan perseroan terbatas lainnya. Bentuk badan usaha dalam pasal 1 angka 1 Undang-Undang No. 19 Tahun 2003 ini sedikit berbeda dengan bentuk badan usaha yang dirumuskan dalam pasal 9 Undang-Undang No. 19 Tahun 2003 yang menentukan bahwa "Badan Usaha Milik Negara terdiri dari Persero dan Perusahaan Umum”. Perbedaan ini tidak terlalu signifikan, karena "perseroan terbatas lainnya" yang terdapat dalam pasal 1 angka 1 tersebut antara lain maksudnya adalah "Persero Terbuka" dan pengaturannya tercakup dalam bab mengenai persero. Tegasnya, baik "Persero" maupun "Persero Terbuka" sama-sama diatur dalam bab 11, pasal $10 \mathrm{~s} / \mathrm{d}$ pasal 34 Undang-Undang Nomor 19 Tahun 2003. Persero diatur dalam pasal $10 \mathrm{~s} / \mathrm{d}$ pasal 33, sementara "Persero Terbuka" diatur dalam pasal 34 (hanya diatur dalam satu pasal saja).

Walaupun pengaturan mengenai persero terbuka ini hanya termuat dalam satu pasal yakni pasal 34 Undang-Undang No. 19 Tahun 2003, namun terhadap perseroan ini berlaku juga ketentuan- ketentuan pasal mengenai persero dan ketentuan-ketentuan pasal mengenai Perseroan Terbatas sebagaimana dimaksud dalam Undang-Undang No. 1 Tahun 1995 serta ketentuan-ketentuan dibidang pasar modal sebagaimana dimaksud dalam Undang-Undang Nomor 8 Tahun 1995, berikut Peraturan pelaksanaannya, seperti Peraturan Pemerintah No. 45 Tahun 1995 Tentang Penyelenggaraan Kegiatan di Bidang Pasar Modal, dan lain sebagainya. Hal ini secara tegas disebutkan dalam pasal 34 Undang-Undang No. 19 Tahun 2003 yang berbunyi: "Bagi Persero Terbuka berlaku ketentuan Undang-Undang ini dan UndangUndang No. I Tahun 1995. sepanjang tidak diatur lain dalam peraturan perundang-undungan dihidang pasar modal"

Bentuk badan usaha milik negara berupa Pemisahan Persero yang lazim disebut Persero dan Perusahaan Umum yang lazim disebut Perum dan perseroan terbatas lainnya, seperti Persero Terbuka, sebagaimana dimaksud dalam pasal 1 angka 10 junto pasal 9 Undang-Undang nomor 19 Tahun 2003, pada umumnya lebih dikenal dengan sebutan "Perusahaan Negara". Penyebutan "Perusahaan Negara" ini pada umumnya dipergunakan dalam rangka membedakan dengan "Perusahaan Swasta". Perusahaan Negara menunjuk pada pengertian perusahaan itu merupakan milik negara atau pemerintah, sedangkan perusahaan swasta bukan milik negara melainkan milik perseorangan atau kelompok individu tertentu, Sebagai Perusahaan milik Negara atau Pemerintah yang tugas/fungsi utamanya untuk menyelenggarakan kepentingan umum (public service), maka Perusahaan Negara diatur dan tunduk pada Hukum Publik, sedangkan Perusahaan Swasta diatur dan tunduk pada hukum privat.

Sebelum terbentuknya Undang-Undang Nomor 1 Tahun 1995 Tentang Perseroan Terbatas dan UndangUndang Nomor 19 Tahun 200? Tentang Badan Usaha Milik Negara, maka berdasarkan Undang-Undang Nomor 9 Tahun 1969 Tentang Bentuk-Bentuk Usaha Negara, maka usaha-usaha negara berbentuk perusahaan dibagi dan dibedakan dalam:

- Perusahaan (Negara) Jawatan atau Department Agency, disingkat Perjan;

- Perusahaan (Negara) Umum atau Public Corpora- 
tion, disingkat Perum dan;

- Perusahaan (Negara) Perseroan, disingkat Persero.

- Perusahaan-perusahaan negara ini ada diatur dalam peraturan perundang-undangan peninggalan Pemerintah Hindia Belanda, tetapi juga sudah ada diatur dalam peraturan perundang-undangan Pemerintah Indonesia merdeka.

Ibrahim. R mengemukakan bahwa perusahaanperusahaan negara pada masa pemerintahan Belanda (sebelum kemerdekaan) hingga pemerintahan Indonesia merdeka (mulai dari pemerintahan orde lama, orde baru), dilihat dari segi peraturannya dapat dibagi dan dibedakan dalam 3 (tiga) macam, yaitu:24

Perusahaan Negara yang diatur dalam Indonesische Bedryven Wet (IBIV), Staatshlad 1927 No. 419.

Anggaran Perusahaan ini dimasukkan dalam Anggaran Belanja Negara, tehnis anggarannya termasuk dalam Departemen Keuangan, sedangkan pengawasannya masing-masing di bawah Departemen Tehnis. Contohnya : Perjan Kereta Api, Perjan Pegadaian, Percetakan Negara, Pusat Perkebunan Rakyat, Pelabuhan Tanjung Priok dan Perusahaan Tambang Batu Bara Bulit Asam;

Perusahaan Negara yang diatur dalam Indische Complahiliteits Wet (ICW). Perusahaan ini tidak tegas berstatus sebagai organisasi/badan usaha yang dilaksanakan pemerintah, namun anggaran perusahaan termasuk dalam anggaran departemen yang bersangkutan.Contohnya: Percetakan Departemen Penerangan, Penerbitan Balai Pustaka, Pabrik Alat Peralatan Perusahaan Listrik Negara Distribusi, Perusahaan Air Minum Negara.

Perusahaan Negara yang diatur diluar ketentuan $\boldsymbol{I B W}$ dan $\boldsymbol{I} \boldsymbol{G} \boldsymbol{W}$, seperti diatur dalam Wethoek van Koophandel ( $\boldsymbol{W v K})$ atau Kitab Undang-Undang Hukum Dagang dan/atau ketentuan Undang-Undang produk pemerintah Indonesia Merdeka, antara lain:

a. Perusahaan Bank Industri Nasional (disebut BAP-INDO, Bank Pembangunan Indonesia), contoh: PT. Perusahaan Tinta Tjetak Tjemani, PT. Pabrik Kertas Blabak, PT. Perusahaan Hotel dan Tourist Nasional;

24 Ibrahirn R. Prospek BUMN dan Kepentingan Umum. (Bandung: Citra Aditya Bakti, 1997), hai. 105-106. b. Perusahaan yang dinasionalisasikan, berdasarkan Undang-Undang Nomor 23 Tahun 1958, Pemer-intah Indonesia menentukan bahwa seluruh peru-sahaan Belanda dibawah pengawasan pemerintah Indonesia;

c. Perusahaan Negara di lapangan Hukum Perdata, seperti: PT. Usaha Pembangunan Perikanan, PT. Pertambangan Timah Belitung, PT. Pertambangan Timah Singkep, PT. Pertambangan Bauxit dan PT. Permina;

d. Perusahaan yang modalnya berasal dan Pemerintah, tetapi dijalankan oleh Yayasan, seperti: Yayasan, Prapanca, Yayayasan Urusan Bahan Ma-kanan, Yayasan Motor, Yayasan Bahan Pertanian, Yayasan Karet Rakyat Pusat, Yayasan Persediaan Bahan Perindustrian.

Dengan menunjuk adanya berbagai peraturan yang mengatur perusahaan negara, baik peraturan dalam Hukum Publik dan Hukum Privat, Ibrahim R lebih lanjut mengatakan bahwa sejak semula telah terjadi kerancuan aspek hukum BUMN. Walaupun upaya penyederhanaan bentuk perusahaan dan penegasan fungsi perusahaan itu kedalam Perjan, Perum dan Persero, tetapi dirasa belum cukup, karena masih banyak BUMN yang berupa perusahaan-perusahaan negara yang mempunyai dasar hukum selain disebutkan dalam 1BW, ICW atau KUHD tersebut di atas, dan dengan demikian bentuknya pun berbeda, seperti Perusahaan Negara, Perseroan Terbatas, Perseroan Terbatas Campuran, Yayasan, Badan Urusan Logistik (Bulog) dan lain sebagainya.25

Tanpa mempersoalkan adanya keanekaragaman peraturan perundang-undangan yang mengatur Perusahaan- perusahaan negara sebagai BUMN, tetapi pada masa pemerintahan reformasi sekarang ini sudah berlaku Undang-Undang Nomor 19 Tahun 2003. Dengan berlakunya Undang-Undang ini seluruh perusahaan-perusahaan negara sudah disederhanakan kedalam perusahaan- perusahaan dengan bentuk Persero atau Perum atau Persero Terbuka atau persero lainnya. Sebagai perusahaan negara, baik yang bentuk Perusahaan Persero atau Perusahaan Umum atau Perusahaan persero lainnya, mempunyai ciri yang utama atau pokok, yakni makna usahanya

25 Ibid, hal. 106 
adalah "public service" yang berarti pengabdian dan pelayanan kepada masyarakat atau singkatnya melayani kepentingan publik (kepentingan umum), maka dengan sendirinya perusahaan- perusahaan negara ini apapun bentuknya kecuali Persero berada dalam Hukum Publik (Public Recht). Hal ini misalnya, ditandai atau dibuktikan dan perusahaan- perusahaan ini pendiriannya berdasarkan Peraturan Pemerintah, bukan berdasarkan Akta Notaris seperti halnya pendirian Perseroan Terbatas pada umumnya.

Ciri utama lainnya dari perusahaan-perusahaan negara sebagai BUMN adalah bahwa modal perusahaan itu baik seluruhnya maupun sebagian merupakan modal negara atau milik negara dan kekayaan negara yang dipisahkan, sehingga keuangan BUMN berupa modal dan keuntungan atau laba yang diperoleh merupakan dan menjadi milik negara atau kekayaan negara dan karenanya dianggap sebagai bagian dari keuangan negara. Dengan kata lain, keuangan yang berada dalam BUMN, baik berupa modal maupun laba atau aset lainnya diakui sebagai bagian dari keuangan negara, baik berdasarkan Undang-Undang Nomor 17 Tahun 2003 Tentang Keuangan Negara, Undang-Undang Nomor 19 Tahun 2003 Tentang BUMN. Undang-Undang Nomor I Tahun 2004 tentang Perbendaharaan Negara, UndangUndang Nomor 15 Tahun 2004 Tentang Pemeriksaan Pengelolaan dan Pertanggungjawaban Keuangan Negara, maupun Peraturan Pemerintah yang mengatur perusahaan-perusahaan negara ataupun peraturan pelaksanaannya.

\section{Badan Usaha Milik Negara (BUMN) Sebagai}

Badan Hukum

Sesuai dengan ketentuan Undang-Undang Nomor 19 Tahun 2003 Tentang Badan Usaha Milik Negara, bentuk badan usaha milik negara terwujud dalam bentuk Perusahaan Persero (disingkat Persero), Perusahaan Umum (disingkat Perum) dan Perusahaan Perseroan Terbuka ( disingkat Persero Terbuka) ataupun perseroan terbatas lainnya. Keseluruhan badan usaha milik negara yang terwujud dalam bentuk perusahaan-perusahaan tersebut dinamakan I disebut Perusahaan negara.
Sebagai Perusahaan negara, Perum adalah BUMN yang seluruh modalnya dimiliki negara dan tidak terbagi atas saham, yang bertujuan untuk kemanfaatan umum berupa penyediaan barang dan/atau jasa yang bermutu tinggi dan sekaligus mengejar keuntungan berdasarkan prinsip pengelolaan perusahaan (pasal 2 angka 4 Undang-Undang Nomor 19 Tahun 2003). Sebelumnya, Perusahaan Umum ini didirikan dan diatur berdasarkan ketentuan-ketentuan yang tercantum dalam Undang-Undang Nomor 19 Prp Tahun 1960. Sekarang ini, Perusahaan Umum sebagai salah satu bentuk BUMN diatur menurut Peraturan Pemerintah Nomor 13 tahun 1998 dalam kaitannya dengan Undang-Undang Nomor 9 Tahun 1969 Tentang Bentuk-Bentuk Usaha negara.

Modal Perum seluruhnya dimiliki oleh negara yaitu berupa kekayaan yang dipisahkan. Hal ini berbeda dengan Perseroan Terbatas yang seluruh modalnya terbagi atas saham, namun modal Perum tidak terbagi atas saham. Perum didirikan dengan Peraturan Pemerintah sekaligus menetapkan keputusan untuk melakukan penyertaan modal negara kedalam Perum. Dengan ketentuan ini Perum memperoleh status badan hukum, setelah Peraturan Pemerintah yang mengatur pendiriannya itu dinyatakan berlaku.

Peraturan Pemerintah mengenai pendirian Perum sekurang-kurangnya memuat:

a. Penetapan pendirian Perum

b. Penetapan besarnya kekayaan negara yang dipisahkan kedalam modal Perum. Pemisahan kekayaan negara untuk dijadikan modal dalam Perum dapat berupa uang tunai atau bentuk lainnya dan disebutkan jumlah atau nilainya. Pemisahan kekayaan negara untuk dijadikan modal dan suatu Perum dapat dilakukan untuk pendirian suatu Perum atau penambahan kapasitas suatu perum atau restrukturisasi permodalan perum. Setiap perubahan penyertaan modal negara ditetapkan dengan Peraturan Pemerintah yang meliputipenambahanatau pengurangan penyertaan modal negara.

c. Anggaran Dasar; dan

d. Penunjukkan Menteri Keuangan selaku Wakil Pemerintah dan pendelegasian wewenang Menteri Keuangan kepada Menteri yang lingkup tugas dan wewenangnya meliputi bidang usaha Perum dalam 
pelaksanaan, pembinaan sehari-hari Perum.

Adapun Perum mempunyai ciri-ciri sebagai

berikut:26

1. Makna usahanya adalah melayani kepentingan umum

2. Berstatus badan hukum, diatur berdasarkan pera-turan perundang-undangan

3. Pada umumnya bergerak di bidang jasa-jasa vital (public Utilities)

4. Mempunyai nama dan kekayaan sendiri serta kebebasan bergerak seperti perusahaan swasta untuk mengadakan atau masuk ke dalam suatu perjanjian, kontrak-kontrak dan hubunganhubun-ganperusahaan lainnya

5. Dapat menuntut dan dituntut dan hubungan hukumnya diatur secara hubungan hukum perdata (privat rechtelijk).

6. Modal seluruhnya, dimiliki oleh negara dan kekayaan negara yang dipisahkan, serta dapat mempunyai dan memperoleh dana dan kreditkredit dalam dan luar negeri atau dan obligasi (dari masyarakat).

7. Pada prinsipnya secara finansial harus dapat berdiri sendiri, kecuali apabila politik Pemerintah menge-nai tarif' dan harga tidak mengizinkan tercapainya tujuan tersebut.

8. Dipimpin direksi.

9. Pegawainya adalah pegawai perusahaan negara yang diatur tersendiri diluar ketentuan-ketentuan yang berlaku bagi PNS atau Pegawai Perusahaan Swasta.

10. Organisasi, tugas, wewenang, tanggung jawab, pertangggungjawaban, dan cara mempertanggungjawabkannya, demikian juga pengawasan dan lain sebagainya diatur khusus yang pada pokoknya tercermin dalam peraturan perundang-undangan yang mengatur pembentuk-kannya.

11. Dalam keadaan tertentu, karena sifatnya ada yang berupa public utility untuk kepentingan umum da-pat melakukan hubungan hukum publik (publick rechttelijk verhouding).

26 I.G. Rai Widjaya, op. cit, hal. 78
12. Laporan tahunan perusahaan yang memuat neraca untung rugi dan neraca kekayaan disampaikan kepada Pemerintah.

Bentuk usaha negara lainnya adalah Perusahaan Persero atau disingkat Pesero. Perusahaan Perseroan adalah BUMN yang berbentuk perseroan terbatas yang modalnya terbagi dalam saham yang seluruh atau paling sedikit 51\% (lima puluh satu persen) sahamnya dimiliki oleh negara Republik Indonesia yang tujuan utamanya mengejar keuntungan (pasal 1 angka 2 Undang-Undang Nomor 19 Tahun 2003). Pengertian persero dalam ketentuan pasal 1 angka 2 Undang-Undang Nomor 19 Tahun 2003 ini identik dengan pengertian Persero sebagaimana diatur dalam Peraturan Pemerintah Nomor 12 Tahun 1998. Dalam pasal 1 PP No. 12 Tahun 1998 ini ditentukan bahwa Persero adalah BUMN yang dibentuk berdasarkan Undang-Undang Nomor 9 Tahun 1969 yang berbentuk Perseroan Terbatas atau PT. yang seluruh atau paling sedikit 51\% (lima puluh satu persen) saham yang dikeluarkannya dimiliki oleh Negara melalui penyertaan modal secara langsung.

Baik ketentuan pasal 1 angka 2 Undang-Undang Nomor 19 Tahun 2003 maupun pasal 1 Peraturan Pemerintah Nomor 12 tahun 1998 mengandung makna bahwa inti dan suatu persero adalah: a. persero itu merupakan BUMN; b. persero itu berbentuk PT, jadi harus sesuai dengan Undang-Undang Nomor 1 tahun 1995 tentang Perseroan Terbatas; c. seluruh sahamnya atau minimum 51\% (lima puluh satu persen) sahamnya dimiliki oleh Negara; d. melalui penyertaan modal secara langsung, yang ditetapkan melalui Peraturan Pemerintah.

Seperti halnya perum, demikian juga persero mempunyai ciri-ciri sebagai berikut:27

- Makna usahanya mencari keuntungan.

- Status hukumnya sebagai badan hukum perdata yang berbcntuk perseroan terbatas,

- Hubungan-hubungan usahanya diatur menurut hukum perdata.

- Modal seluruhnya atau sebagian (minimum 51\% sahamnya) dimiliki Negara.

- Tidak memiliki fasilitas-fasilitas negara.

- Dipimpin suatu direksi

27 I.G Rai Widjaya, op cit. hal. 103 - 104. 
- Pegawainya berstatus sebagai pegawai perusahaan swasta biasa.

- Peranan Pemerintah adalah sebagai pemegang saham dalam perusahaan.

Pada bagian lain, Persero Terbuka adalah merupakan salah satu bentuk BUMN yang diatur dalam peraturan perundang-undangan. Persero Terbuka adalah Persero yang modal dan jumlah pemegang sahamnya memenuhi kriteria tertentu atau Persero yang melakukan penawaran umum sesuai peraturan perundang-undangan di bidang pasar modal (pasal 1 angka 3 UU No. 19 Tahun 2003). Menurut ketentuan, persero terbuka ini berlaku ketentuan perundang-undangan di bidang pasar modal yaitu Undang-Undang Nomor 8 Tahun 1995 berikut Peraturan Pelaksanaannya. Selain itu ditentukan juga bahwa perseroan yang sahamnya telah dimiliki sekurang- kurangnya oleh 300 (tiga ratus) pemegang saham dan memiliki modal yang disetor sekurang-kurangnya tiga milyar rupiah atau yang ditetapkan dengan Peraturan Pemerintah.

Sesuai ketentuan pasal 34 Undang-Undang Nomor 19 Tahun 2003, bagi Persero Terbuka berlaku ketentuan Undang-Undang Nomor 1 tahun 1995 Tentang Perseroan Terbatas, selain ketentuan di bidang pasar modal. Oleh karena itu bagi Persero Terbuka terdapat hal-hal yang sama dengan Perseroan Terbatas, misalnya ketentuan mengenai cara pendirian, organ persero, yakni Rapat Umum Pemegang Saham (RUPS), Direksi dan Komisaris, dan lain sebagainya.

Dari ketentuan peraturan perundang-undangan yang mengaturnya, maupun dari ciri-cirinya, seluruhnya perusahaan negara itu baik berbentuk Perum, Persero ataupun Persero Terbuka status hukumnya atau berkedudukan sebagai badan hukum. Dengan kata

lain BUMN itu ada umumnya adalah berkedudukan sebagai badan hukum, baik badan hukum publik maupun badan hukum privat BUMN dalam bentuk perusahaan negara itu (perum, persero dalam persero terbuka) dikategorikan sebagai badan hukum publik, yang berbeda dengan Perseroan Terbatas menurut Undang-Undang Nomor 1 Tahun 1995 yang berstatus badan hukum privat. Pengklasifikasian badan hukum kedalam badan hukum publik dan badan hukum privat adalah pembagian badan hukum menurut

jenisnya. Selain pembagian badan hukum menurut jenisnva, tetapi juga ada pembagian badan hukum menurut macamnya, menurut sifatnya dan pembagian lainnya.28

Secara umum sudah diakui bahwa di Indonesia kriteria yang dipakai untuk menentukan sesuatu badan hukum apakah termasuk badan hukum publik atau termasuk badan hukum privat ada 2 (dua) macam, yaitu:29

1. Kriteria berdasarkan terjadinya. Jika badan atau badan usaha itu didirikan perseorangan atau kelompok tertentu, maka badan usaha itu merupakan badan usaha privat, sedangkan jika badan usaha itu didirikan Pemerintah/ Negara, maka badan usaha itu merupakan badan hukum publik:

2. Kriteria berdasarkan lapangan kerjanya. Jika badan usaha itu dalam lapangan pekerjaan untuk kepentingan perseorangan,, maka badan usaha itu merupakan badan hukum privat, sedangkan jika badan usaha itu dalam lapangan pekerjaan untuk kepentingan umum, maka badan usaha itu merupakan badan hukum publik. Badan Usaha yang termasuk dalam kategori badan hukum privat, misalnya: Perseroan Terbatas, Koperasi dan Yayasan, sedangkan badan usaha yang termasuk dalam kategori badan hukum publik, misalnya Negara RI, Pemerintah Daerah Tingkat I, Pemerintah Daerah Tingkat II, Pemerintah Kota,

Perusahaan-Perusahaan Negara (BUMN),

Bank-Bank Negara seperti Bank Indonesia.

Badan Usaha Milik Negara (BUMN) yang terwujud dalam bentuk usaha Perusahaan Negara sebagai badan hukum tentu tunduk pada ketentuan di bidang badan hukum yang termasuk dalam ranah (wilayah kajian) Hukum Privat, tepatnya Hukum Perdata. Dalam ketentuan peraturan perundangan dalam bidang Hukum Privat, tepatnya dalam pasal $1653 \mathrm{KUH}$

28 Chidir Au, Badan Hukum (Bandung : Alumni, 1999), hal. 55

29 Ridwan Sjahrani. Seluk Beluk dan Asas-asas Hukum Perdata Bandung: Alumni, 2004), hal 55 
Perdata, ditentukan syarat-syarat agar suatu badan atau badan usaha, termasuk juga perkumpulan dapat disebut mempunyai kedudukan sebagai suatu badan hukum. Syarat-syarat suatu badan baru berkedudukan sebagai badan hukum sebagaimana diatur dalam peraturan perundang-undangan dapat dibedakan atas pernyataan tegas ataupun pernyataan secara tidak tegas dalam undang-undang. Sebagai contoh Perseroan Terbatas menurut pasal 1 Undang-Undang Nomor 1 Tahun 1995 dinyatakan secara tegas sebagai badan hukum. Demikian juga BUMN yang diwujudkan ke dalam bentuk perusahaan negara sebagaimana diuraikan dan diatur dalam peraturan perundangan yang dinyatakan secara tegas sebagai badan hukum.

Disamping syarat-syarat yang ditentukan dalam peraturan perundang-undangan mengenai badan hukum, tetapi juga syarat-syarat yang harus dipenuhi oleh suatu badan/badan usaha / perkumpulan agar dapat disebut sebagai badan hukum menurut doktrin. Menurut doktrin, syaratsyarat itu adalah sebagai berikut:30

Adanya harta kekayaan yang terpisah. Harta kekayaan ini diperoleh dari anggota/para anggota maupun dari perbuatan perusahaan yang dilakukan oleh perseroan/swasta/ pemerintah untuk suatu tujuan tertentu. Adanya harta kekayaan ini dimaksudkan sebagai alat atau sarana untuk mencapai tujuan badan hukum tersebut,

Mempunyai tujuan tertentu. Tujuan tertentu dapat berupa tujuan idiil maupun materiil yang merupakan tujuan tersendiri daripada badan hukum.

Mempunyai kepentingan sendiri Maksudnya ialah untuk mencapai tujuannya badan hukum mempunyai kepentingan sendiri yang dilindungi hukum. Kepentingan-kepentingan tersebut merupakan hak-hak subjektif sebagai akibat dan perbuatan ataupun peristiwa hukum. Oleh karena itu badan hukum, sebagaimana layaknya manusia, dapat mempertahankan dan menuntut haknya terhadap pihak lain dalam hubungan-hubungan hukum.

Ada organisasi yang teratur. Maksudnya badan

30 ibid. hal $57-58$ hukum itu merupakan suatu organ. Badan Hukum adalah konstruksi juridis. Oleh karena itu sebagai objek hukum. Oleh karena itu, sebagai subjek hukum disamping manusia, badan hukum hanya dapat melakukan perbuatan hukum dengan perantaraan organnya. Organ badan hukum yang terdiri dari manusia itu bertindak mewakili badan hukum, organ itu dipilih atau diganti diatur dalam anggaran dasarnya yang memuat peraturan-peraturan mengenai pembagian tugas. Dengan demikian badan hukum itu mempunyai organisasi yang teratur.

Secara historis sudah diakui bahwa badan hukum adalah subjek hukum, selain manusia. Sebagai subjek hukum, maka badan hukum diakui sebagai pendukung, pemilik, pengemban hak dan kewajiban dalam hubungan hukum sebagaimana layaknya manusia. Memang ada pendapat yang menyatakan bahwa manusia adalah subjek hukum orang, sedangkan badan hukum adalah juga subjek hukum tetapi subjek hukum bukan orang. Namun demikian, teori-teori mengenai badan hukum, baik teori yang berusaha kearah peniadaan persoalan badan hukum maupun yang berusaha tetap mempertahankan persoalan badan hukum adalah dalam rangka/memperoleh hakekat badan hukum. Dalam ilmu pengetahuan hukum, sekurang-kurangnya dikenal 5 (lima) teori, yakni :

1. Teori Fiksi, 2. Teori Harta kekayaan Bertujuan. 3. Teori Teori Organ. 4. Teori Propriété Collective dan 5. Teori Kenyataan Yuridis. 31

\section{Analisis Hukum Terhadap Keuangan BUMN}

\section{Se-bagai Keuangan Negara}

Berdasarkan syarat-syarat, teori- teori dan penggolongan 1 pembagian mengenai badan hukum sebagaimana diuraikan diatas dapat diketahui bahwa baik negara disatu segi maupun BUMN di lain segi adalah sama-sama sebagai Badan Hukum. Dalam konsep (perspektif) hukum privat, baik negara sebagai badan hukum maupun BUMN sebagai badan hukum merupakan badan yang terpisah satu sama lain, sehingga

31 Di samping kelima teori mengenai badan hukum tersebut. Chaidir Ali masih menambahkan/menyebut satu teori lagi. yakni Teori "Leer van het amhtelijk vermogen" bandingkan : Chidir Ali, op. cit. hal $32-35$ 
masing-masing badan hukum (negara) ataupun badan hukum (BUMN) sekalipun termasuk dalam badan hukum publik, tetapi dapat melakukan perbuatan hukum di bidang Hukum Privat atau Hukum Perdata, misalnya melakukan perjanjian. Dalam kaitannya dengan masalah keuangan, dalam perspektif (konsep) hukum privat sudah tentu keuangan negara terpisah dengan keuangan BUMN. Dengan adanya pemisahan keuangan itu. sekalipun keduanya merupakan badan hukum publik dan pengaturannya dalam hukum publik, tetapi karena kekayaan negara yang berasal dan keuangan negara itu dipisahkan, maka otomatis (demi hukum) seharusnya sudah menjadi milik dan merupakan bagian keuangan BUMN, sehingga tidak boleh lagi disebut sebagai bagian dan keuangan negara. Tegasnya, dalam perspektif Hukum Privat, tepatnya Hukum Perdata yang mengatur dan mengenai Badan Hukum, keuangan BUMN merupakan kekayaan BUMN tersendiri yang terlepas dan bukan lagi bagian dari keuangan negara.

Konsep Hukum Privat mengenai badan hukum dan keuangan seperti tersebut di atas, ternyata berbeda dengan konsep Hukum Publik, khususnya yang menyangkut kekayaan negara. Peraturan perundangundangan dalam bidang Hukum Publik yang mengatur mengenai keuangan negara, mulai dan UUD 1945, baik pra amandemen maupun pasca amandemen,

UU No. 17 Tahun 2003 Tentang Keuangan Negara, UU No. 19 Tahun 2003 Tentang BUMN, UU No. 15 Tahun 2004 Tentang Pemeriksaan Pengelolaan dan Pertanggungjawaban Keuangan Negara, hingga UU No. 31 Tahun 1999 sebagaimana ditambah dengan UU No. 20 Tahun 2001 Tentang Pemberantasan korupsi dan juga UU. No. 2 Tahun 2003, pada hakekatnya menganut atau mengikuti keuangan negara dalam arti luas, termasuk dalam hal ini kekayaan yang telah dipisahkan ke dalam BUf4N tetap dianggap sebagai keuangan negara. Oleh karena itu, jika ada direksi atau pegawai pada BUMN yang merugikan keuangan negara sudah pasti dapat dituntut sebagai tersangka pelaku tindak pidana korupsi dalam perspektif Hukum Publik tersebut, sedangkan jika dalam perspektif
Hukum privat perbuatan orang tersebut bukan tindak pidana korupsi, melainkan tindak pidana penggelapan, ada konsekuensi hukum yang berbeda dalam hal apakah keuangan negara atau tidak.

Apabila konsep Hukum Privat dipertahankan, dalam arti baik negara sebagai badan hukum maupun BUMN sebagai bahan hukum dan keuangan negara terpisah dengan keuangan BUMN, tentunya orang yang menyelewengkan uang pada BUMN itu dapat dituduh sebagai pelaku tindak pidana penggelapan (eks pasal 372 KUHP), tetapi jika dianggap keuangan BUMN itu merupakan bagian dan keuangan negara sekalipun sebelumnya sudah dipisahkan untuk tujuan tertentu, maka orang tersebut akan dituduh sebagai tersangka pelaku tindak pidana korupsi dengan alasan orang tersebut merugikan keuangan negara. Dari segi konsep hukum mengenai badan hukum, pengertian keuangan dalam arti luas sebagaimana diatur dalam peraturan perundang-undangan dibidang hukum publik seperti tersebut diatas, adalah tidak tepat.

Dianutnya, pengertian keuangan negara dalam arti luas dalam konsep Hukum Publik seperti disebutkan diatas mendapat kritik pedas dan para ahli, sebagaimana disitir oleh Dian Puji N. Simatupang, 32 dengan mengutip pendapat Arifin P. Soeria Atmadja dan Jusuf Indradewa. Dalam kritiknya Arifin P. Soeria Atmadja menyatakan sebagai berikut: "UU No. 17 Tahun 2003 tentang Keuangan Negara, dapat diartikan undang-undang tersebut merupakan undangundang organik dan Pasal 23 C UUD 1945. Namun, ternyata substansi yang diatur dalam undang-undang tersebut bukan mengenai hal-hal lain keuangan Negara, tetapi mengenal penyusunan APBD, APBD, hubungan keuangan antara Pemerintah dan Perusahaan Negara, Perusahaan Daerah, Perusahaan Swasta, serta badan pengelola dana masyarakat diluar domein hukum keuangan negara. Pembuat undang-undang tidak memahami perbedaan prinsipiil antara keuangan negara, keuangan daerah, keuangan perusahaan negara maupun perusahaan daerah. Bahkan keuangan swastapun diatur dalam undang-undang keuangan

32 Dian Puji N. Simatupang, Determinasi Kebijakan Anggaran Negara Indonesia, Studi Yuridis, op. cit. hal 54 -55 
negara ini"

Sehubungan pengertian luas mengenai keuangan negara, berarti juga pengawasan BPK terhadap pengelolaan dan pertanggungjawaban keuangan negara semakin luas, artinya pengawasan BPK itu tidak hanya terhadap pelaksanaan APBN (sebagai keuangan negara), tetapi juga terhadap kekayaan negara (yang merupakan bagian dan keuangan negara). Dalam konteks ini, tepat apa yang dikatakan oleh Jimly Asshiddiqie, bahwa pengertian kekayaan negara yang harus diperiksa oleh BPK berkembang menjadi sangat luas termasuk juga kekayaan pihak lain yang diperoleh oleh pihak yang bersangkutan dengan menggunakan fasilitas yang diberikan oleh pemerintah. Bahkan kekayaan pihak lain yang dikuasai pemerintah dalam rangka penyelenggaraan tugas pemerintahan dan/atau kepentingan umum dikategorikan pula sebagai kekayaan pemerintah yang harus diperiksa oleh BPK. ${ }^{33}$

Demikian juga Jusuf Indradewa memberi kritik terhadap pengertian keuangan negara dalam arti luas itu sebagai pengingkaran atas konsepsi keuangan negara yang menghilangkan status uang secara terpisah sesuai konsep hukum. Dengan mengatakan sebagai berikut:

“...perlu sekali lagi ditegaskan bahwa keuangan Negara adalah keuangan yang sepenuhnya menjadi hak dan kekayaan Negara sebagai Badan Hukum. Sementara itu. Daerah sebagai Badan Hukum mempunyai keuangan sendiri yang terpisah dan keuangan negara, yang oleh Undang-Undang Otonomi Daerah disebut sebagai Keuangan Daerah. Demikian pula hal-nya dengan BUMN Persero sebagai Badan Hukum yang mempunyai status kemandirian, memiliki keuangan atau kekayaan sendiri yang terpisah dan kekayaan Negara sebagai pemegang saham.

Dengan mengacu pada kritik ahli tersebut, Dian puji $N$ Simatupang menyatakan bahwa: secara prinsip $U U$ No. 17 Tahun 2003 tidak membedakan status uang dan kepemilikan kekayaan dalam suatu badan, apakah itu

33 Jimly Asshiddiqie, Formal Kelembagaan Negara dan Pergeseran Kekuasaan Dalam UUD 1945, (Yogyakarta FH UH Press), hal. 157 milik negara, milik daerah, milik BUMN, milik BUMD, atau milik swasta atau perseorangan.

Pada dasarnya pengaturan yang demikian justru menyalahi konsep buku yang secara tegas membedakan antara milik publik dan milik privat. Hal ini sesuai dengan pendapat Utrecht bahwa maksud kepunyaan negara adalah apa yang ditentukan sebagai milik negara dalam suatu peraturan biasa, juga yang ditentukan dalam peraturan kkusus yang disebut sebagai kepunyaan publik (publick domein). 34

Adapun kepunyaan publik (publick domein) diartikan sebagai "segala benda yang disediakan oleh pemerintah untuk dipakai oleh (pergaulan), umum, seperti: jalan umum dan jembatan. Di sisi lam, negara sebagai badan hukum juga mempunyai hak keperdataan yang tunduk pada ketentuan hukum perdata. Dengan demikian hukum menentukan pembedaan kedudukan negara sebagai badan hukum publik yang tunduk pada peraturan perundangundangan yang bersifat publik dan negara sebagai badan hukum privat yang tunduk pada kekuatan hukum privat.

Demikian juga dalam ketentuan Undang-Undang Nomor 1 Tahun 2004, hal yang sama seperti dalam Undang-Undang Nomor 17 Tahun 2003 tersebut tetap terjadi, karena dalam Undang-Undang Nomor 1 Tahun 2004 ini juga tidak membedakan status kedudukan hukum tentang uang, terbukti dan pengertian/ definisi perbendaharaan negara dinyatakan sebagai "pengelolaan dan pertanggungjawaban keuangan negara, termasuk investasi dan kekayaan yang dipisahkan yang ditetapkan dalam APBN dan APBD”. Hal ini berarti kebijakan keuangan negara di Indonesia tidak memberikan tempat pada pembedaan status dan kedudukan hukum mengenai uang yang ideal, padahal pembedaan itu diperlukan dalam kerangka mempermudah pemeriksaan, pengawasan dan pertanggungjawaban keuangan negara yang dikelola pemerintah.
34 Dian Puji N. Simatupang, Hukum Anggaran Dan Keuangan Negara, op. cit. hal 182 


\section{Kesimpulan dan Saran}

Sebagai penutup dari penulisan ini, akan diajukan simpulan dan saran. Simpulan di sini merupakan jawaban atas pembahasan pokok permasalahan berdasarkan analisis hukum, baik dan aspek peraturan perundang-undangan dan pendapat para ahli maupun dan teori-teori yang ada yang berkaitan dengan pokok permasalahan yang dibahas.Sementara itu, saran merupakan solusi atau jalan keluar yang ditawarkan terhadap permasalahan itu sendiri. Peraturan perundang-undangan yang mengatur mengenai keuangan negara menganut konsep keuangan negara dalam arti luas, maksudnya keuangan negara itu tidak hanya mencakup keuangan dalam APBN saja, tetapi juga mencakup APBN yang dipisahkan kepada Pemerintah Daerah (APBD), kepada BUMN, kepada BUMD dan kepada badan lainnya serta seluruh harta kekayaan milik negara yang dapat dinilai dengan uang.

Dengan demikian, keuangan dalam APBN maupun keuangan yang sudah dipisahkan menjadi keuangan APBD.menjadi keuangan BUMN, menjadi keuangan BUMD, dan menjadi keuangan badan lainnya, serta seluruh keuangan negara yangmerupakan suatu sistem keuangan negara. Undang-Undang Nomor 17 Tahun 2003 Tentang Keuangan Negara, Undang-Undang Nomor 19 Tahun 2003 Tentang Badan Usaha Milik Negara, Undang-Undang Nomor 1 tahun 2004 Tentang Perbenda $\neg$ haraan Negara, Undang-Undang Nomor 15 Tahun 2004 Tentang Pemeriksaan Pengelolaan dan Pertanggungjawaban Keuangan Negara dan Peraturan Perundang-undangan lainnya, termasuk UUD 1945 pasca amandemen yang merupakan peraturan perundangundangan di bidang keuangan negara adalah termasuk bidang hukum publik. Dengan demikian konsep hukum publik mengenai keuangan negara menganut konsep keuangan negara dalam arti luas.

Oleh karena itu konsep hukum publik berpendapat bahwa keuangan BUMN yang berasal dan keuangan APBN yang sudah dipisahkan tetap dianggap sebagai bagian dan keuangan negara.Singkat kata, keuangan BUMN adalah bagian dan keuangan negara. Berbeda halnya dengan konsep hukum publik, maka hukum privat terutama hukum perdata yang mengatur mengenai badan hukum berpendapat bahwa keuangan BUMN adalah terpisah dan bukan merupakan bagian dan keuangan negara. Dalam konsep ini BUMN sebagai badan hukum seperti halnya negara yang juga sebagai badan hukum publik menganggap bahwa baik BUMN maupun negara merupakan dua badan yang terpisah dan masing-masing mempunyai keuangan atau kekayaan sendiri-sendiri.Dengan konsep yang demikian tampak secara jelas adanya perbedaan status dan kedudukan uang, sedangkan dalam konsep hukum publik di Indonesia di bidang keuangan tidak memberikan tempat pada perbedaan status dan kedudukan uang tersebut.Tegasnya, dan perspektif analisis hukum, tidak tepat untuk menyatakan keuangan BUMN sebagai bagian dan keuangan negara.

Sudah saatnya melakukan perubahan atau amandemen terhadap peraturan perundang-undangan yang mengatur mengenai keuangan negara dan diharapkan dalam perubahan itu memuat konsep hukum yang membedakanstatus dan kedudukan uang, sehingga dapat diketahui keuangan BUMN merupakan keuangan yang terpisah dan bukan merupakan bagian dan keuangan negara. Hal ini sesuai dengan konsep hukum yang melihat BUMN sebagai badan hukum, demikian juga halnya negara sebagai badan hukum. Hendaknya Badan Pemeriksa Keuangan (BPK), baik sebagai lembaga tinggi negara, maupun sebagai lembaga pengawas eksternal terhadap pengelolaan dan pertanggungjawaban keuangan negara, lebih memfokuskan diri pada fungsi pengawasan yang bersifat post - audit dan tidak lagi melakukan fungsi pengawasan yang bersifat pre - audit, karena selain menimbulkan kesan bahwa BPK sebagaimana layaknya audit internal pemerintah dan karenanya dianggap sebagai bagian dan pemerintah, tetapi juga dengan melakukan hal itu BPK menjadi turun derajatnya ataupun kedudukannya sebagai lembaga tinggi negara dan dianggap tidak bebas dan tidak mandiri. 


\section{DAFTAR PUSTAKA}

\section{A.BUKU-BUKU}

Ais, C’hatamarrasjid, 2002. Badan Hukum Yayasan (Suatu Analisis Mengenai Yayasan Sebagai Suatu Badan Hukum Sosial), cet. I, Bandung: Citra Aditya Bakti.

Ali, Chidir, 1999. Badan Hukum, cet. Ll. Bandung: Alumni.

Asshiddiqie, Jimly, 1994. Gagasan Kedaulatan Rakyat Dalam Konstitusi dan Pelaksanaannya di Indonesia, cet. 1. Jakarta: Ichtiar Baru van Hoeve. 2004. Format

Kelembagaan Negara dan Pergeseran Kekuasaan Dalam UUD 1945, cet. 1, Yogyakarta: FH - UII Press.

Atmadja, Arifin P. Soeria, 1986, Mekanisme Pertanggungjawaban Keuangan Negara, Suatu Tinjauan Yuridis, cet. I, Jakarta: Gramedia.

Attamimi, A. Hamid. S, "Pengertian Keuangan Negara Menurut UUD 1945 Pasal 23 dalam : Wahjono, Padmo.1984,Masalah Ketatanegaraan Indonesia Dewasa Ini, Cet. I, Jakarta: Ghalia Indonesia.

Basri, Yuswar Zainul \& Subri, Mulyadi, 2003, Keuangan Negara dan Analisis Kebijakan Utang Luar Negeri, cet. I, Jakarta: Raja Grafindo Persada.

Bohari, H, 1995, Hukum Anggaran Negara, cet. I, Jakarta: Raja Grafindo Persada.

Husen, La Ode, 2005, Hubungan Fungsi Pengawasan Dewan Perwakilan Rakyat Dengan Badan Pemeriksa Keuangan Dalam Sistim Ketatanegaraan Indonesia, cet. L Bandung : CV. Utomo.

Muhammad, Abdul Kadir, 2004. Hukum Dan

Penelitian Hukum, cet. I. Bandung: Citra Aditya Bakti

Nugraha, Sairi, 2005, Hukum Administrasi Negara, cet. I, Jakarta Badan Penerbit Fakultas Hukum Universitas Indonesia.

R, Ibrahim, 1997, Prospek BUMN dan Kepentingan Umum, cet. 1, Bandung: Citra Aditya Bakti.

Rido, Ali, 1986, Badan Hukum dan Kedudukan Badan Hukum Perseroan, Perkumpulan Koperasi, Yayasan, Wakaf Cet. IV. Bandung: Alumni
Soekamto, Soerjono, 1986. Pengantar Penelitian Hukum. cet. I. Jakarta: Penerbit Universitas Indonesia.

Soekamto, Soerjono \& Mamudji, Sri. 2003. Penelitian Hukum Normatif cet. L Jakarta: Raja Grafindo Persada

Simatupang, Dian Puji N, 2005, Determinasi Kebakan Anggaran Negara Indonesia, Studi Yuridis, Cet. I, Jakarta : Papas Sinar Sinanti

Sjahrani, Riduan, 2004, Seluk Beluk dan Asas-Asas Hukum Perdata, cet. IV, Bandung: Alumni

Soepangat, Edi \& Lumban Gaol, Haposan, 1991. Pengantar Ilmu Keuangan Negara, cet. I, Jakarta: STIE Perbanas dan PT. Gramedia Pustaka Utama.

Subagio, M, 1988. Hukum Keuangan Negara RI, Cet. I, Jakarta: Rajawali Press.

Tjandra, W. Riawan, 2006, Hukum Keuangan Negara, Cet. I, Jakarta: Grasindo. , 2004, Dinamika Peran Pemerintah Dalam Perspektif Hukum Administrasi, cet. I,

Yogyakarta : Universitas Atmajaya.

Widjaya, I.G. Rai, 2002, Hukum Perusahaan. Cet. I, Jakarta Megapoin.

\section{B.PERATURAN PERUNDANG- UNDANGAN}

Indonesia, Undang-Undang Nomor 17 Tahun 2003 Tentang Keuangan Negara.

Indonesia, Undang-Undang Nomor 19 Tahun 2003

Tentang Badan Usaha Milik Negara.

Indonesia, Undang-Undang Nomor 1 Tahun2004

Ten-tang Perbendaharaan Negara.

Indonesia, Undang-Undang Nomor 15 Tahun 2004

Tentang Pemeriksaan Pengelolaan Dan

Pertang-gung jawaban Dan Keuangan Negara

Sekretariat Jenderal Mahkamah Konstitusi RI,

Undang-Undang Dasar Negara Republik

Indonesia Tahun 1945 Dan Undang-Undang RI 